Genevieve Dingle, Dianna Vidas \& Mengxun Hong

2020

School of Psychology The University of QLD

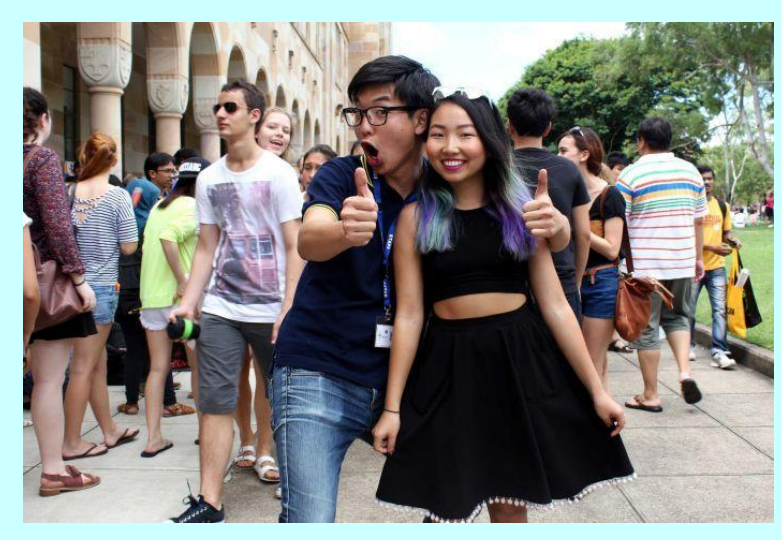

\section{STRESS, WELLBEING, AND HELP SEEKING IN FIRST YEAR UNIVERSITY STUDENTS}

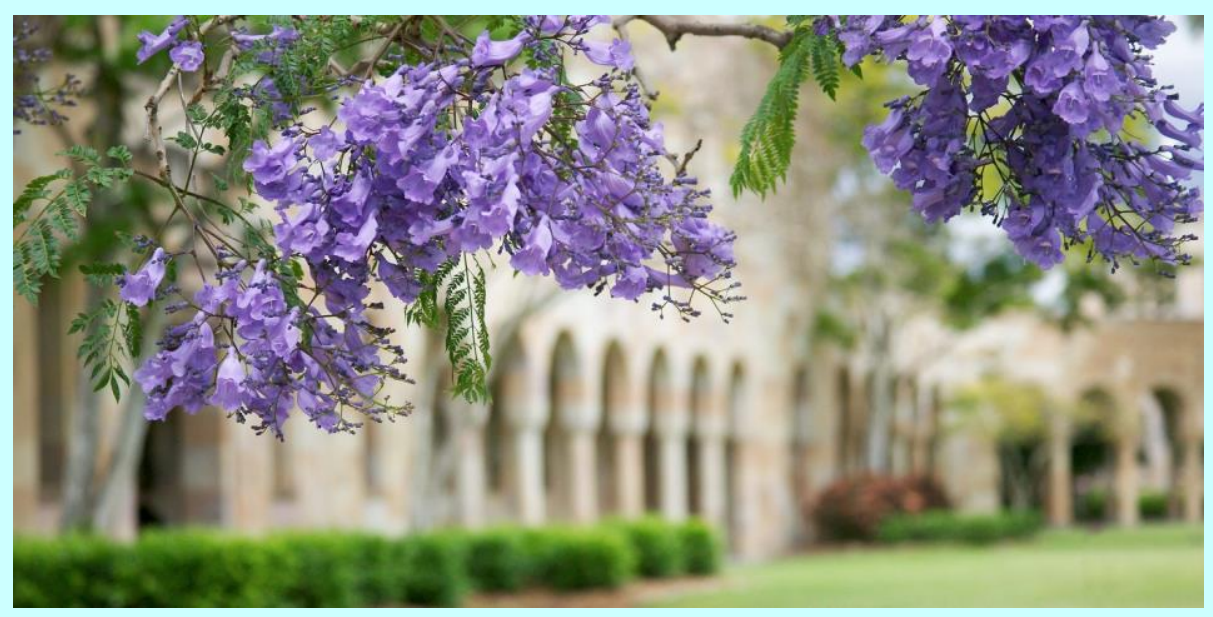




\section{Table of Contents}

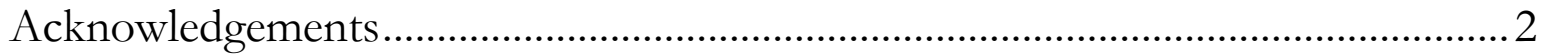

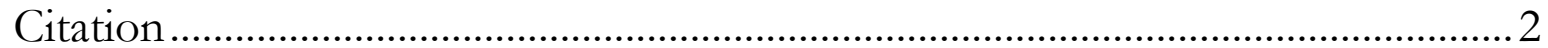

Project Ethics Approval and Pre-registration ..................................................... 2

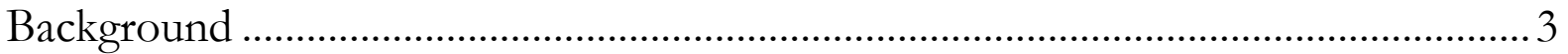

Aims and Objectives ......................................................................................... 3

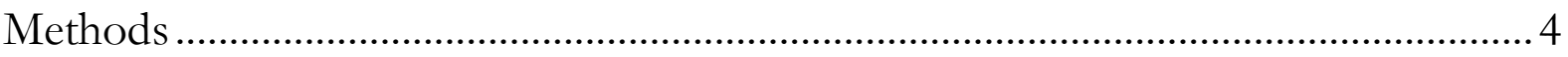

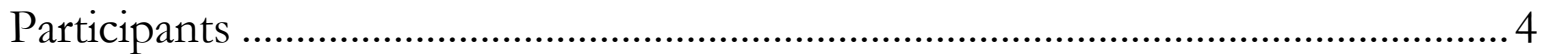

Table 1. Demographic Characteristics …………………….................................. 4

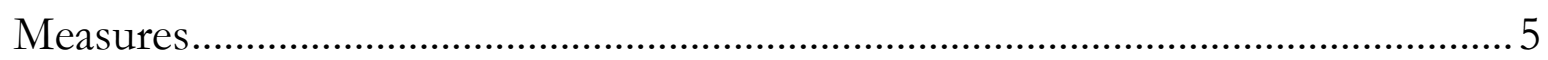

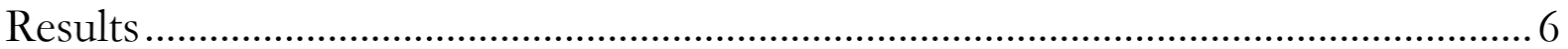

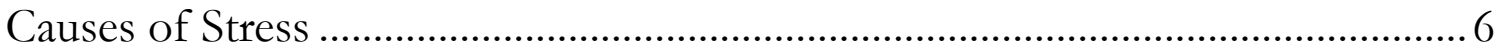

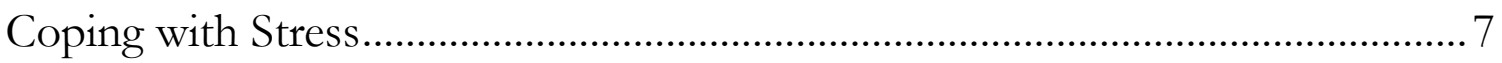

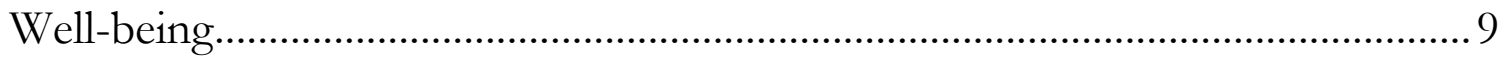

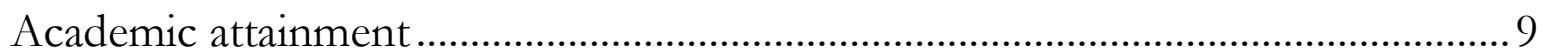

Relationships between coping strategies and outcomes ............................................ 9

Table 2. Correlations of coping strategies and key outcome variables for

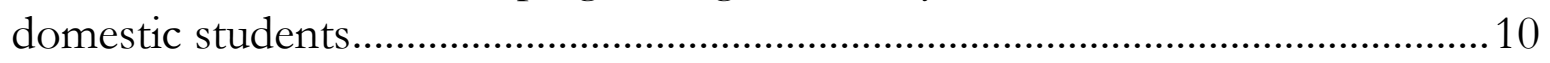

Table 3. Correlations of coping strategies and key outcome variables for

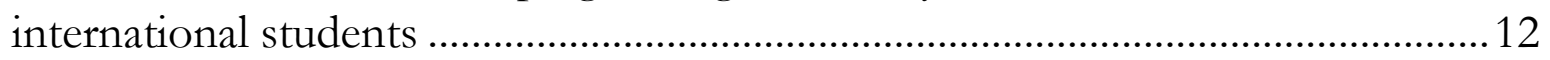

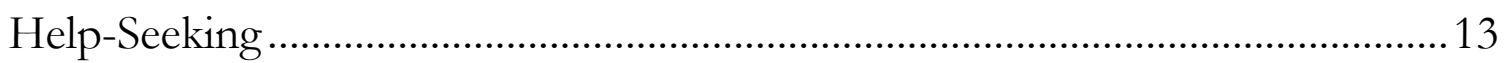

Table 4. Barriers to Help-Seeking ………………............................................. 14

Discussion and Recommendations ......................................................................15

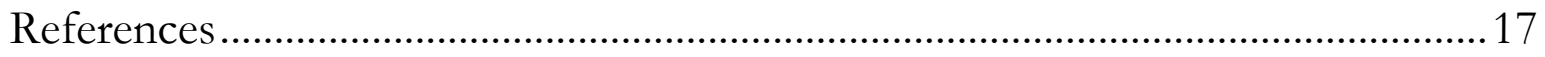




\section{Acknowledgements}

The authors would like to sincerely thank all of the participants, the Schools of Psychology, Business and Pharmacy, Vicki Bos and the ICTE, International student administrator Meg Cridland, student advisors Jun Ian Lim, Germaine Lai, Natanat Tanongsakmontri and Eeliz Puah, Shaun Hayes and International House College, and Roxana Paterson and Grace College.

\section{Citation}

Dingle, G., Vidas, D., \& Hong, M. (2020) Stress, Wellbeing, and Help Seeking in First Year University Students. School of Psychology, The University of QLD.

Project Ethics Approval and Pre-registration

University of QLD HREC 2019001150 


\section{Background}

According to WHO data, roughly half of all lifetime mental disorders onset by the mid-teens and three quarters by the mid-20s (Kessler et al., 2007). This means that most undergraduate students are in the age range of most risk for mental illness onset. In addition, a 2010 study reported that the prevalence of mental health problems in students at the University of Queensland is approximately $20 \%$, a rate significantly higher than in the general population rate of around 3\% (Australian Bureau of Statistics, 2008). In addition, almost $65 \%$ of students in this study reported sub-syndromal symptoms (Stallman, 2010).

The international education industry has rapidly become a strong support for the Australian economy, accounting for $22 \%$ of economic income in 2018. In 2018, there were 693,750 full-fee paying international students in Australia on a student visa. This was a 10\% increase on 2017 and the numbers continue to grow (Department of Education and Training, 2018). For international students, adjusting to life in Australia can be stressful and challenging. As well as experiencing common causes of stress reported by young people in Australia, international students may encounter additional difficulties related to language, finances, interpersonal relationships (Mori, 2000), homesickness, culture shock, or perceived discrimination (Russell, Rosenthal, \& Thomson, 2010). Therefore, it is important to support the health and wellbeing of international students during their temporary stay in Australia.

\section{Aims and Objectives}

The aims of the project were to survey first year students from various faculties of the University about the factors that cause them to feel stressed, what coping strategies they find most helpful, what their preferred help-seeking options are and what potential barriers prevent them from seeking help when required.

Furthermore, the project investigated the well-being and mental health of domestic and international first-year students and correlated these measures with their end of semester academic achievement (GPA scores). 


\section{Methods}

This project had a longitudinal design, including a 'snapshot' survey during weeks 2 to 7 of semester 2, and end of semester academic outcomes (GPA). Participants were recruited to voluntarily complete the online survey at the end of class time and they were offered a chance to enter a prize draw for vouchers or they completed it in return for 0.5 hours course credit for introductory Psychology courses.

\section{Participants}

Participants were recruited through pilot schools Pharmacy, Business, Psychology, ICTE, several residential colleges, and word of mouth. The final population included 475 participants, of whom $61.9 \%$ were domestic students, and $38.1 \%$ were international students. The average age for international students was 21.61 years, and for domestic students, 18.89 years. Other demographic variables are summarised in Table 1.

Table 1. Demographic Characteristics

\begin{tabular}{|c|c|c|}
\hline Characteristic & $\begin{array}{l}\text { International Students } \\
\qquad(N=181)\end{array}$ & $\begin{array}{c}\text { Domestic Students } \\
(N=294)\end{array}$ \\
\hline \multicolumn{3}{|l|}{ Gender } \\
\hline Female & $61.9 \%$ & $73.8 \%$ \\
\hline Male & $35.2 \%$ & $25.9 \%$ \\
\hline Prefer not to say & $2.2 \%$ & $0.3 \%$ \\
\hline \multicolumn{3}{|l|}{ Citizenship } \\
\hline Australian & $\mathrm{N} / \mathrm{A}$ & $81 \%$ \\
\hline Chinese & $79.6 \%$ & $\mathrm{~N} / \mathrm{A}$ \\
\hline Others & $19.9 \%$ & $4 \%$ \\
\hline Dual-Citizens & $0.6 \%$ & $12.9 \%$ \\
\hline \multicolumn{3}{|l|}{ Living situations } \\
\hline Living with family & $3.3 \%$ & $62.6 \%$ \\
\hline Share-house & $35.9 \%$ & $15.3 \%$ \\
\hline UQ College & $7.2 \%$ & $12.2 \%$ \\
\hline $\begin{array}{l}\text { Shared student } \\
\text { accommodation }\end{array}$ & $26.5 \%$ & $3.4 \%$ \\
\hline Student accommodation & $21 \%$ & $1.7 \%$ \\
\hline Living alone & $6.1 \%$ & $4.4 \%$ \\
\hline
\end{tabular}




\section{Measures}

The online survey included a number of validated self-report measures, and we met with 4 international student advisors to consider each question in relation to comprehension and relevance to international students. The measures included:

- Stress items drawn from the APS Stress and Wellbeing Survey (Casey \& Liang, 2014). We added other items specific to our study such as class presentations and group assignments.

- Coping strategies from Thayer, Newman, and McClain (1994). We separated these into individualised strategies and group based strategies, and added items specific to our study.

- Social Participation Questionnaire (Densley, Davidson, \& Gunn, 2013)

- Short Warwick Edinburgh Mental Wellbeing Scale (Stewart-Brown et al., 2009)

- PsyCheck measure (Jenner, Cameron, Lee, \& Nielsen, 2013), which screens for anxiety, depression and somatic symptoms of distress

- AUDIT-C measure of alcohol misuse (Bradley et al., 1998). 


\section{Results}

\section{Causes of Stress}

In terms of causes of stress, international students perceived eight causes as significantly more stressful than domestic students. These causes were aspects of academic study (Figure 1) such as the stress of having to complete written assignments and written exams, as well as stress related to daily living (Figure 2) such as concerns regarding personal safety, workplace issues, living arrangements, disclosing ones sexuality to others, and finding paid work. Importantly, international students had mean stress ratings above 3 (on a scale from $1=$ strongly disagree to $5=$ strongly agree) for all components of academic study.

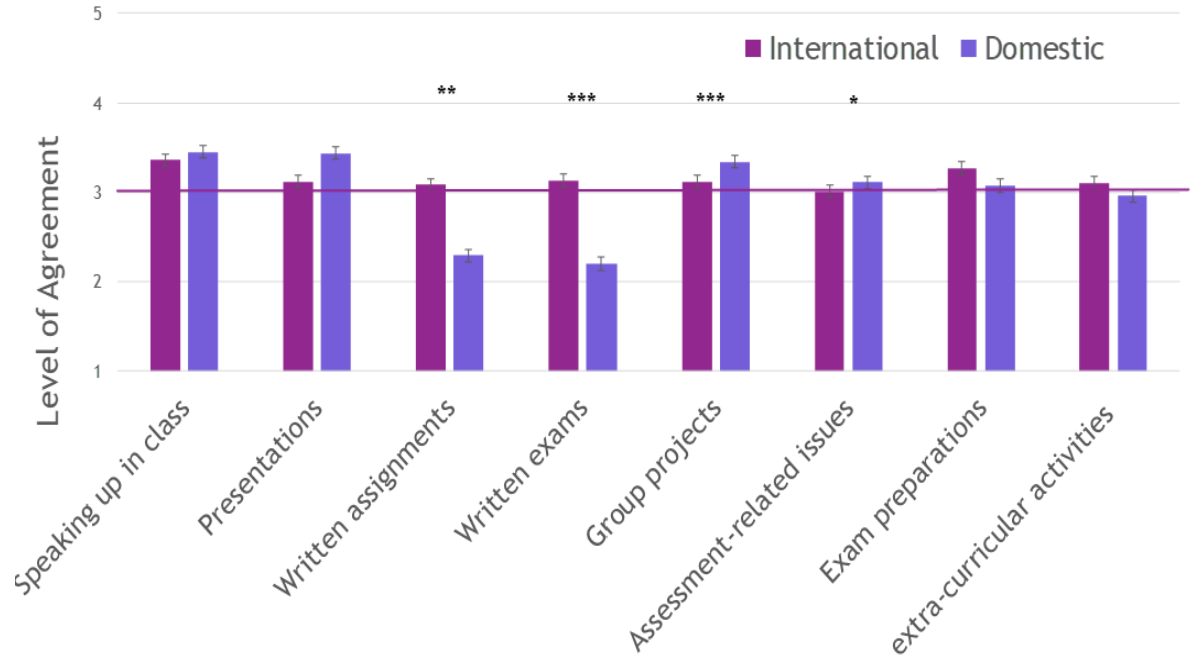

Figure 1. Academic causes of stress for international and domestic students

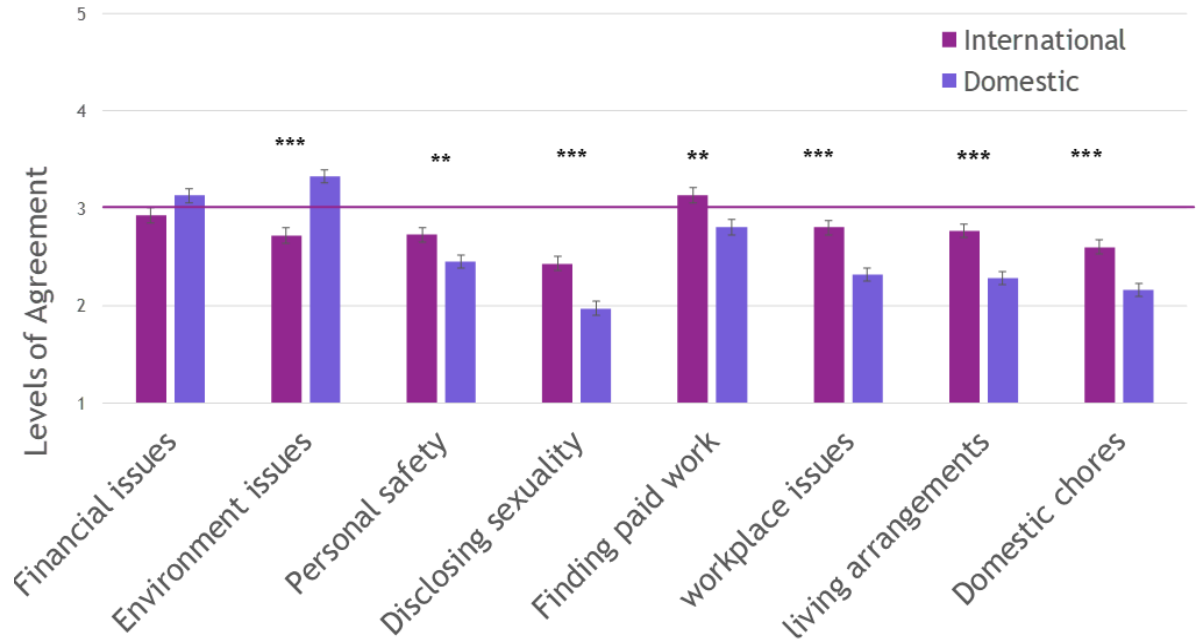

Figure 2. Other causes of stress for international and domestic students. 
On the other hand, domestic students scored higher on five causes of stress compared to international students: class presentations, group projects, mental health issues, concerns regarding the environment, and maintaining a healthy lifestyle (Figures 2 and 3). Overall, levels of stress reported by both groups were moderate; however, domestic students reported a significantly greater number of stressors (8.12 stressors on average) than international students ( 6.95 stressors on average), $\mathrm{t}(473)=-2.45, p=.015$.

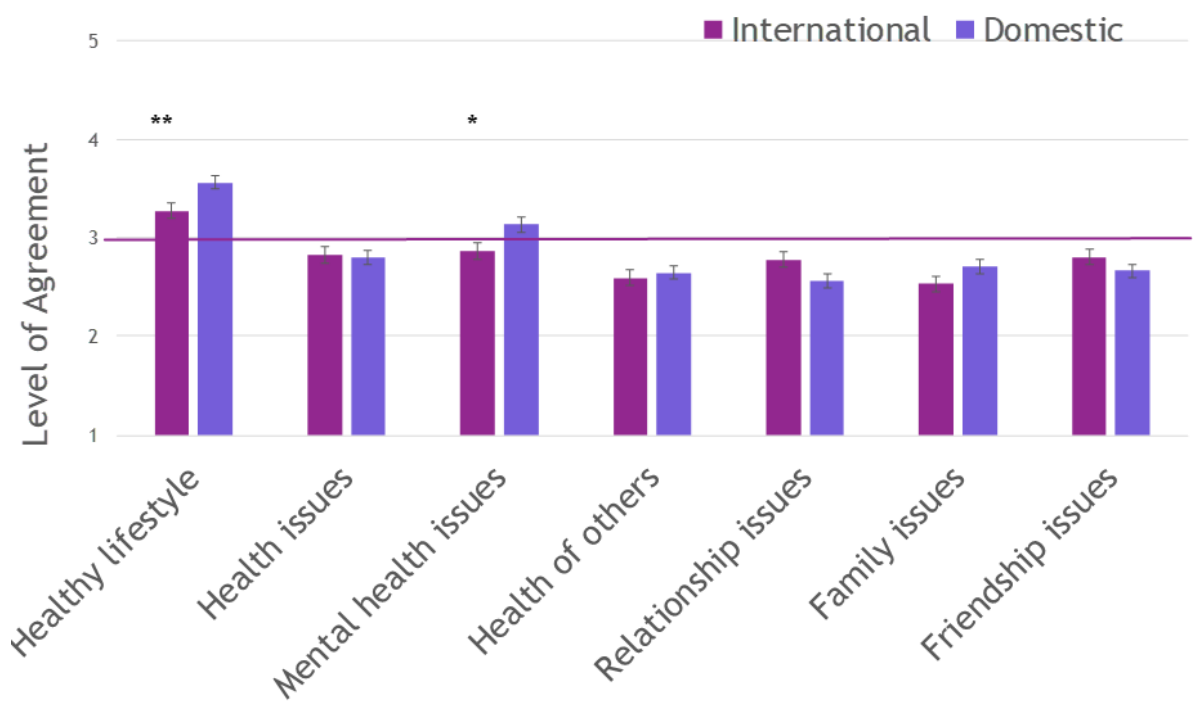

Figure 3. Health and relationships causes of stress for international and domestic students.

\section{Coping with Stress}

Whilst students reported a large number of stressors, they also reported that a number of different methods are effective at managing their stress. Some methods of coping with stress are individual, as shown in Figure 4. Numerous coping strategies are effective for both international students and domestic students, particularly music listening. 


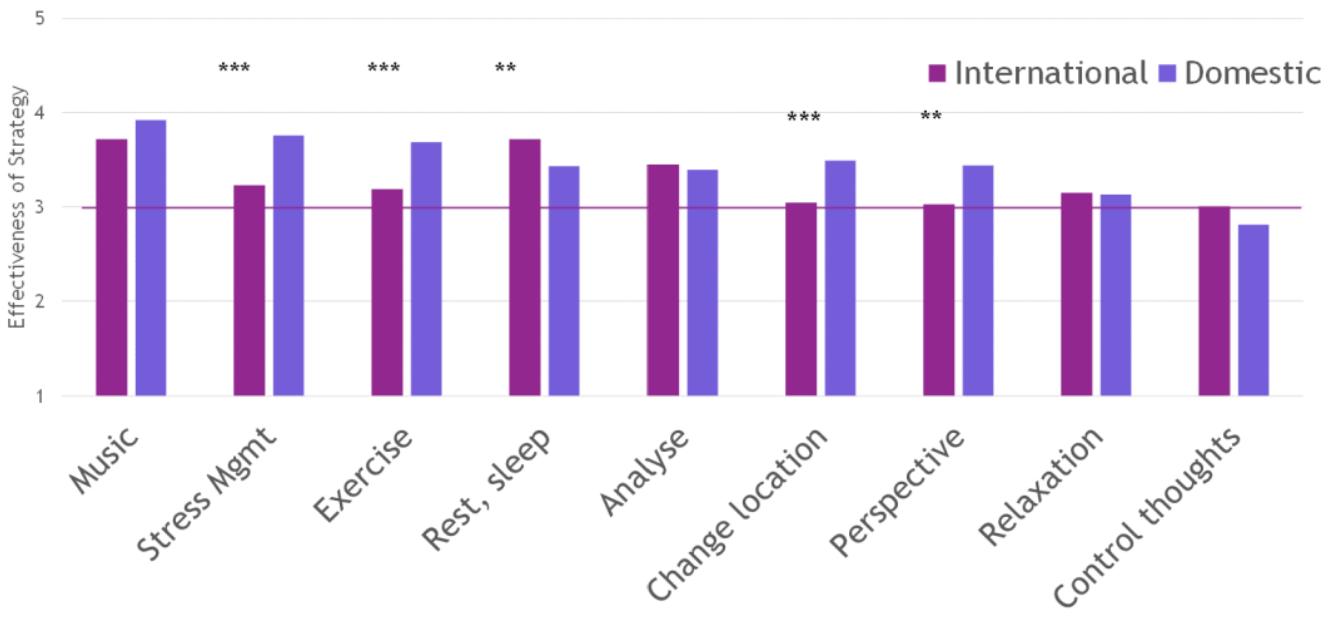

Figure 4. How often international and domestic university students found the following individualised coping strategies effective (scale of $1=$ none of the time to $5=$ all of the time).

Other methods of coping with stress are more social or group based. These are shown in Figure 5. Combined with the individual coping strategies, students have a range of strategies at their disposal to use when coping with stress.

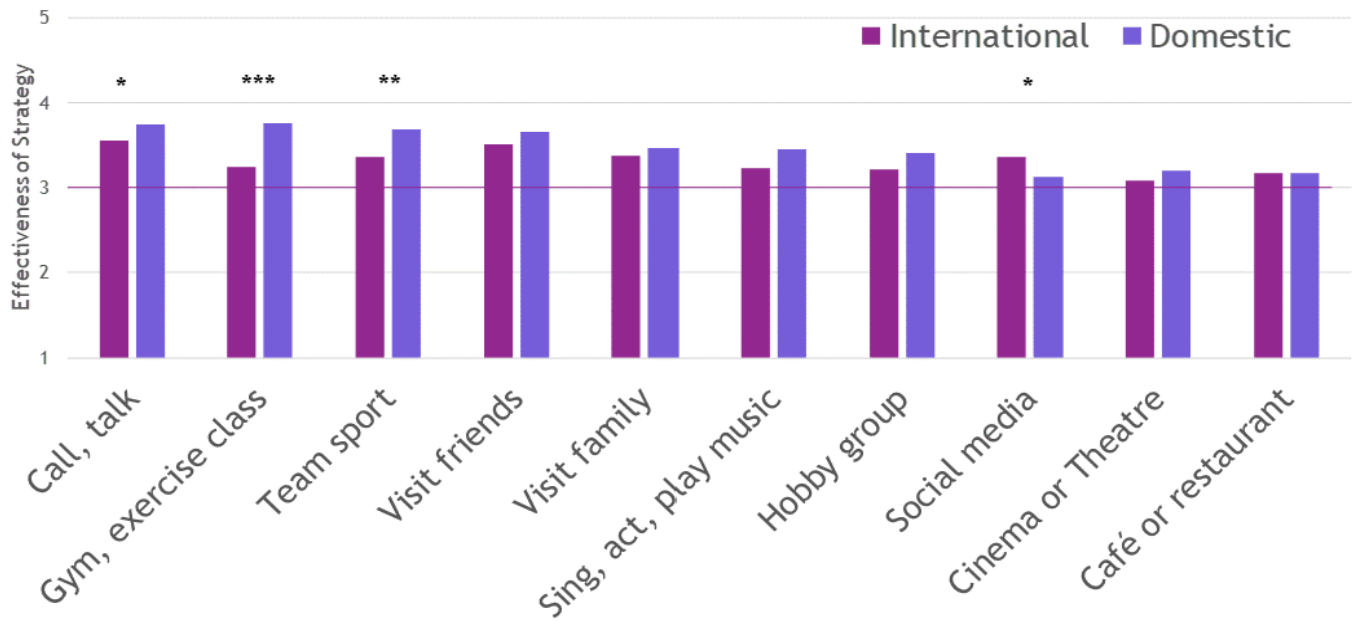

Figure 5. Effective group coping strategies for domestic and international students 


\section{Well-being}

For the short Warwick Edinburgh Mental Wellbeing Scale, the scores range from 7 to 35 , with higher scores indicating better well-being. On average, 16-24 year olds show scores around 23-24 (Ng Fat, Scholes, Boniface, Mindell, \& Stewart-Brown, 2017). In our study, average wellbeing scores for UQ students were slightly lower in domestic $(M=21.44, S D=4.03)$ and international students $(M=21.57, S D=$ 4.05) than the published norms for young adults, although international and domestic students scored similarly.

For the PsyCheck questionnaire, the maximum possible number of symptoms was 20 symptoms, and cut-off scores between 5 and 8 symptoms indicate considerable symptoms of depression, anxiety and/or somatic complaints (Jenner et al., 2013). Scores on the PsyCheck questionnaire indicated that domestic students $(M=8.45$, $S D=5.44)$ reported significantly more psychological disturbance compared with international students $(M=5.53, S D=4.78), F(1,352)=34.12, p<.001$. Both domestic and international students may be struggling with their mental health, as has been reported previously (Stallman, 2010).

For the screen for alcohol use disorders (Audit-C), higher scores indicate more alcohol misuse, with scores above 3 for women and 4 for men indicating alcohol misuse (Bradley et al., 1998). The Audit- $C$ indicated that domestic students ( $M=$ 3.88, $S D=2.87)$ showed more risky alcohol consumption than international students $(M=2.17, S D=1.89), F(1,407)=53.82, p<.001$.

\section{Academic attainment}

A subsample of 225 students gave active consent for us to retrieve their end of semester GPA data (181 domestic students and 44 international students), and there was no difference in mean GPA between domestic $(M=5.44, S D=1.23)$ and international $(M=5.21, S D=0.89)$ students.

\section{Relationships between coping strategies and outcomes}

As expected, the number of stressors students perceived was negatively associated with well-being, and positively related to PsyCheck scores, meaning that students who experienced stress from multiple aspects of life had poorer psychological wellbeing and reported more mental health symptoms (see Table 2). In the case of domestic students, GPA was negatively associated with the number of reported stressors, such that students with higher grades reported fewer stressors and 
symptoms. Meanwhile, In addition, GPA was found to negatively associate with a variety of stressors, including financial issues, mental health issues, health issues, family issues, issues about disclosing sexuality to others, issues in the workplace, and issues with living arrangements.

Table 2. Correlations of coping strategies and key outcome variables for domestic students

\begin{tabular}{|c|c|c|c|c|}
\hline & 1. GPA & $\begin{array}{l}\text { 2. Number } \\
\text { of Stressors }\end{array}$ & 3. PsyCheck & $\begin{array}{l}\text { 4. Well-being } \\
\text { (SWEMWB) }\end{array}$ \\
\hline 1. GPA & 1 & & & \\
\hline $\begin{array}{l}\text { 2. Number of } \\
\text { Stressors }\end{array}$ & $-.16^{*}$ & 1 & & \\
\hline 3. PsyCheck & $-.18^{*}$ & $.52 * *$ & 1 & \\
\hline $\begin{array}{l}\text { 4. Well-being } \\
\text { (SWEMWB) }\end{array}$ & .047 & $-.34 * *$ & $-.59 *$ & 1 \\
\hline $\begin{array}{l}\text { 5. Effectiveness: } \\
\text { music listening }\end{array}$ & -.048 & -.091 & -.090 & .068 \\
\hline $\begin{array}{l}\text { 6. Effectiveness: } \\
\text { stress management }\end{array}$ & $.182 *$ & -.069 & $-.246^{* * *}$ & $.275^{* * *}$ \\
\hline $\begin{array}{l}\text { 7. Effectiveness: } \\
\text { rest, nap, sleep }\end{array}$ & -.014 & -.097 & .036 & .075 \\
\hline $\begin{array}{l}\text { 8. Effectiveness: } \\
\text { Exercise }\end{array}$ & .022 & $-.133^{*}$ & -.105 & .052 \\
\hline $\begin{array}{l}\text { 9. Effectiveness: } \\
\text { analyse situation }\end{array}$ & .024 & $-.180^{* *}$ & $-.317 * * *$ & $.400 * * *$ \\
\hline $\begin{array}{l}\text { 10. Effectiveness: talk } \\
\text { to someone }\end{array}$ & -.035 & -.043 & -.052 & $.207 * * *$ \\
\hline $\begin{array}{l}\text { 11. Effectiveness: } \\
\text { visit friends }\end{array}$ & $-.177 *$ & $-1.33^{*}$ & -.098 & $.230 * * *$ \\
\hline $\begin{array}{l}\text { 12. Effectiveness: } \\
\text { gym/exercise class }\end{array}$ & -.049 & $-.154 *$ & -.092 & .122 \\
\hline $\begin{array}{l}\text { 13. Effectiveness: } \\
\text { sport }\end{array}$ & .063 & -.003 & -.058 & .070 \\
\hline 14. Visit family & .029 & $-.201 * *$ & $-.170 * *$ & $.268 * * *$ \\
\hline
\end{tabular}

Note. ${ }^{*} \mathrm{p}<.05,{ }^{* *} \mathrm{p}<.01,{ }^{* * *} \mathrm{p}<.001$ 
For the domestic students, Table 2 shows the correlations among the top five rated individual and top five social coping strategies with outcomes (GPA, wellbeing and psychological symptoms). The pattern of results indicates that some coping strategies are related to several positive outcomes (such as analyse difficult situations), whereas some strategies are related to positives in terms of stress and wellbeing yet negatively related to GPA (such as visiting friends or family).

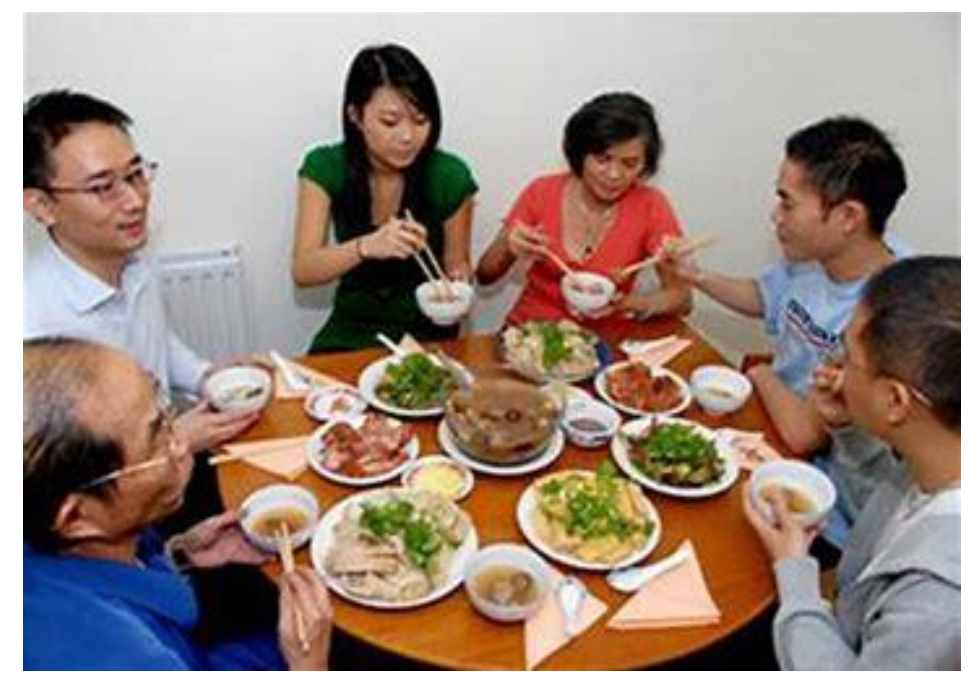

Figure 5. Among the first year international students, visiting friends and family were related to better well-being (see Table 3).

For the international students, Table 3 shows that there were no significant relationships revealed between GPA and well-being variables. Using stress management techniques (such as goal setting and time management) and analysing a difficult situation were the only coping strategies associated with better GPA.

The effectiveness of music listening as a coping strategy was linked with better well-being and less psychological distress. In addition, the effectiveness of sport and exercise classes as a coping strategy related to better well-being. Visiting friends and talking to someone was also related to better well-being. 
Table 3. Correlations of coping strategies and key outcome variables for international students

\begin{tabular}{|c|c|c|c|c|}
\hline & 1. GPA & $\begin{array}{l}\text { 2. Number } \\
\text { of Stressors }\end{array}$ & 3. PsyCheck & $\begin{array}{l}\text { 4. Well-being } \\
\text { (SWEMWB) }\end{array}$ \\
\hline 1. GPA & 1 & & & \\
\hline $\begin{array}{l}\text { 2. Number of } \\
\text { Stressors }\end{array}$ & .19 & 1 & & \\
\hline 3. PsyCheck & .10 & .10 & 1 & \\
\hline $\begin{array}{l}\text { 4. Well-being } \\
\text { (SWEMWB) }\end{array}$ & .03 & -.14 & $-.55^{* *}$ & 1 \\
\hline $\begin{array}{l}\text { 5. Effectiveness: } \\
\text { music listening }\end{array}$ & .185 & .023 & $-.270 * * *$ & $.281 * * *$ \\
\hline $\begin{array}{l}\text { 6. Effectiveness: } \\
\text { stress mgmt }\end{array}$ & $.465^{* *}$ & $.188 *$ & -.071 & $.206^{*}$ \\
\hline $\begin{array}{l}\text { 7. Effectiveness: } \\
\text { rest, nap, sleep }\end{array}$ & -.066 & .089 & -.090 & .046 \\
\hline $\begin{array}{l}\text { 8. Effectiveness: } \\
\text { Exercise }\end{array}$ & .314 & .075 & $-.191 *$ & .145 \\
\hline $\begin{array}{l}\text { 9. Effectiveness: } \\
\text { analyse situation }\end{array}$ & $.453^{* *}$ & .053 & $-.161 *$ & $.319 * * *$ \\
\hline $\begin{array}{l}\text { 10. Effectiveness: } \\
\text { talk to someone }\end{array}$ & .076 & .011 & -.150 & $.219 * *$ \\
\hline $\begin{array}{l}\text { 11. Effectiveness: } \\
\text { visit friends }\end{array}$ & .034 & .050 & $-.232 * *$ & $.318^{* * *}$ \\
\hline $\begin{array}{l}\text { 12. Effectiveness: } \\
\text { gym/ex. class }\end{array}$ & .039 & .075 & $-.315^{* * *}$ & $.298 * * *$ \\
\hline $\begin{array}{l}\text { 13. Effectiveness: } \\
\text { sport }\end{array}$ & .154 & .092 & $-.324 * * *$ & $.214^{*}$ \\
\hline 14. Visit family & .010 & .094 & -.070 & $.225^{* *}$ \\
\hline
\end{tabular}

Note. ${ }^{*} \mathrm{p}<.05,{ }^{*} \mathrm{p}<.01,{ }^{* * *} \mathrm{p}<.001$ 


\section{Help-Seeking}

Beyond using their own coping strategies, there are numerous ways students may access help through the university. For example, face-to-face counselling at the UQ Psychology Clinic, student services, a school advisor, and their tutors. In addition, online messaging, and counselling, as well as telephone counselling are other options. Both international and domestic students expressed a preference to seek help face-to-face at the UQ clinic, and international students also said they would seek help at student services and from an academic advisor. Preference for online / SMS or telephone based support was lower than expected. Figure 6 summarises the results.

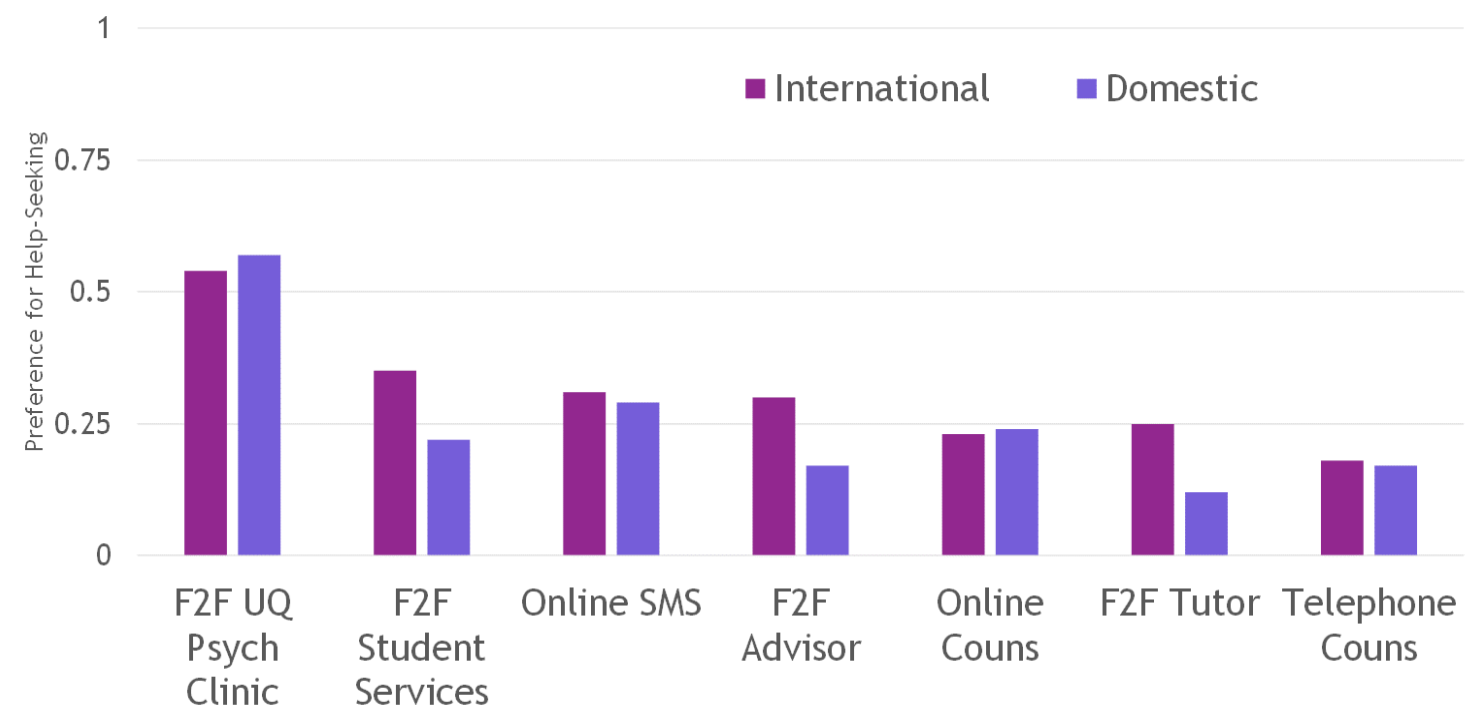

Figure 6. Preferred help-seeking resources as a \% of students 
Finally, domestic students reported more barriers to seeking help (2.49 barriers on average) compared with international students (1.9 barriers on average). Table 4 shows the barriers to seeking help for the sample, and the differences between the groups. The most commonly reported barrier to seeking help in both groups was thinking that their problem wasn't important enough.

Table 4. Barriers to Help-Seeking

\begin{tabular}{|c|c|c|}
\hline Barriers to Help-Seeking & $\begin{array}{c}\text { International } \\
\text { students } \\
(N=164)\end{array}$ & $\begin{array}{c}\text { Domestic } \\
\text { students } \\
(N=290)\end{array}$ \\
\hline Problem is not important enough $*$ & $34.1 \%$ & $57.2 \%$ \\
\hline Language barrier $*$ & $30.5 \%$ & $1 \%$ \\
\hline Too busy * & $26.8 \%$ & $42.4 \%$ \\
\hline $\begin{array}{l}\text { Lack of confidence that therapists can } \\
\text { help * }\end{array}$ & $18.9 \%$ & $36.2 \%$ \\
\hline Don't want family to know * & $18.9 \%$ & $28.6 \%$ \\
\hline $\begin{array}{c}\text { Cultural difference in therapist } \\
\text { understanding * }\end{array}$ & $16.5 \%$ & $3.8 \%$ \\
\hline Family doesn't understand & $14.6 \%$ & $20.3 \%$ \\
\hline Don't want friends to know $*$ & $12.2 \%$ & $20 \%$ \\
\hline Worry it will affect my grades & $11 \%$ & $15.9 \%$ \\
\hline Stigma $*$ & $6.1 \%$ & $23.8 \%$ \\
\hline
\end{tabular}

Note. An asterisk $(*)$ indicates a significant difference between groups. 


\section{Discussion and Recommendations}

The survey revealed that domestic students reported a greater number of stressors than international students overall, whereas the international students reported more components of academic study as causes of stress. The survey indicates that domestic and international students show similar levels of well-being, a positive outcome given that research suggests that international students may be at risk of many stressors (Rosenthal, Russell, \& Thomson, 2006). Indeed, domestic students reported significantly more stressors and more psychological symptoms than international students, and also showed more risky alcohol consumption. Furthermore, GPA is similar between domestic and international students, and for domestic students at least, higher semester GPA is associated with reporting fewer stressors and fewer psychological symptoms earlier in the semester.

Students reported that a number of strategies are effective at managing their stress, including personal music listening, using structured stress management techniques, exercising, talking to others and participating in exercise classes. These strategies were selectively related to outcomes in that some were beneficial for academic attainment while others were beneficial for mental health and wellbeing.

In terms of help seeking, the only form of support that was rated as acceptable by a majority of students was face to face support at the UQ Psychology Clinic. Other forms of support were favoured by around a quarter of students or fewer. Unfortunately, both domestic and international students reported numerous barriers to help-seeking. Many students believe that their issues are not important enough to warrant seeking help, and international students in particular are concerned about the language barriers that may impede their ability to get help.

These findings suggest that University staff could better communicate to students where to seek help and that it is available to anyone who considers that they are struggling. There may also be a role for culture and language-specific peer supporters within Schools and Centres of the University (e.g., students from higher years supporting first year students who are struggling). 
Overall, it is crucial that students are made aware of the resources available to them, particularly for face-to-face help, but also the online resources available to all students (see https://my.uq.edu.au/contact/student-life\#qt-contact student lifefoundation-tabs-1 and screen shot below for range of supports). It is important that students feel comfortable seeking help regardless of the perceived size of their issue, in order for them to tackle any issues they encounter when adjusting to university.

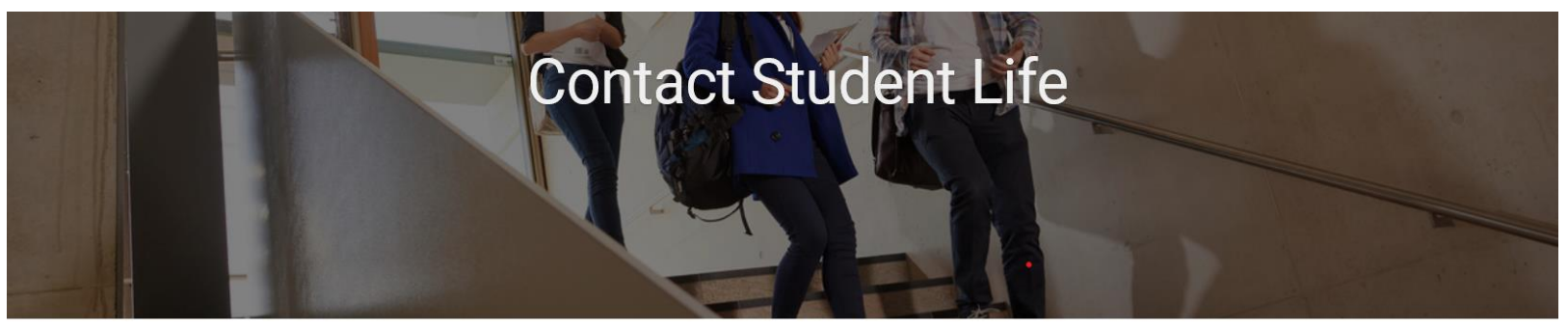

- / Information and services / Student support

Call us, email us or come see us!

If you have any questions, or you'd like to book an appointment, we're happy to help. 


\section{References}

Australian Bureau of Statistics. (2008). National Survey of Mental Health and Wellbeing: Summary of Results. Canberra. Retrieved from

http://www.ausstats.abs.gov.au/ausstats/subscriber.nsf/0/6AE6DA447F985FC2CA2574 EA00122BD6/\$File/National Survey of Mental Health and Wellbeing Summary of Results.pdf

Bradley, K. A., McDonell, M. B., Bush, K., Kivlahan, D. R., Diehr, P., \& Fihn, S. D. (1998). The AUDIT Alcohol Consumption Questions. Alcoholism: Clinical \& Experimental Research, 22(8), 1842. https://doi.org/10.1097/00000374-199811000-00034

Casey, L., \& Liang, R. P.-T. (2014). Stress and wellbeing in Australia in 2014: The state of the nation three years on. The Australian Psychological Society, (October), 1-54.

Densley, K., Davidson, S., \& Gunn, J. M. (2013). Evaluation of the Social Participation Questionnaire in adult patients with depressive symptoms using Rasch analysis. Quality of Life Research, 22(8), 1987-1997. https://doi.org/10.1007/s11136-013-0354-4

Jenner, L., Cameron, J., Lee, N. K., \& Nielsen, S. (2013). Test-retest reliability of PsyCheck: A mental health screening tool for substance use treatment clients. Advances in Dual Diagnosis, 6(4), 168-175. https://doi.org/10.1108/ADD-03-2013-0008

Kessler, R. C., Amminger, G. P., Aguilar-Gaxiola, S., Alonso, J., Lee, S., \& Üstün, T. B. (2007). Age of onset of mental disorders: A review of recent literature. Current Opinion in Psychiatry, 20(4), 359-364. https://doi.org/10.1097/YCO.0b013e32816ebc8c

Ng Fat, L., Scholes, S., Boniface, S., Mindell, J., \& Stewart-Brown, S. (2017). Evaluating and establishing national norms for mental wellbeing using the short Warwick-Edinburgh Mental Well-being Scale (SWEMWBS): findings from the Health Survey for England. Quality of Life Research, 26(5), 1129-1144. https://doi.org/10.1007/s11136-016-1454-8

Rosenthal, D. A., Russell, V. J., \& Thomson, G. D. (2006). A Growing Experience: The Health and Well-Being of International Students at the University of Melbourne. Melbourne, Australia.

Stallman, H. M. (2010). Psychological distress in university students: A comparison with general population data. Australian Psychologist, 45(4), 249-257. https://doi.org/10.1080/00050067.2010.482109

Stewart-Brown, S., Tennant, A., Tennant, R., Platt, S., Parkinson, J., \& Weich, S. (2009). Internal construct validity of the Warwick-Edinburgh Mental Well-Being Scale (WEMWBS): A Rasch analysis using data from the Scottish Health Education Population Survey. Health and Quality of Life Outcomes, 7, 1-8. https://doi.org/10.1186/1477-7525-7-15

Thayer, R. E., Newman, J. R., \& McClain, T. M. (1994). Self-Regulation of Mood: Strategies for Changing a Bad Mood, Raising Energy, and Reducing Tension. Journal of Personality and Social Psychology, 67(5), 910-925. https://doi.org/10.1037/0022-3514.67.5.910 